\title{
CADASIL affecting a black African man
}

Louis Vlok, MD, and Naeem Brey, MD

Neurol Genet 2018;4:e270. doi:10.1212/NXG.0000000000000270

Correspondence

Dr. Vlok

drlouisvlok@gmail.com

Cerebral autosomal dominant arteriopathy with subcortical infarcts and leukoencephalopathy (CADASIL) is an important genetic cause of strokes and vascular dementia. ${ }^{1}$ The disease is characterized by 5 main symptoms: migraines, subcortical ischemic events, mood disturbances, apathy, and cognitive impairment.

The causative mutation lies in the Notch 3 gene on chromosome 19. The gene encodes for the NOTCH3 protein, which is expressed in vascular smooth muscle cells, and mutations lead to the development of arterial stenosis. ${ }^{1}$

CADASIL has been described mostly in Caucasian families, but has been diagnosed infrequently in Arabian ${ }^{2}$ and Asian families. ${ }^{3}$ Only 1 case report on an African American family has been previously published. ${ }^{4}$ There are no cases documenting indigenous black sub-Saharan African patients.

\section{Case report}

The patient is a 36-year-old black Zimbabwean man. He awoke one morning with right-sided hemiparesis. There was no history of a prior stroke-like episode. The patient denied social risk factors and reported occasional migraine-like headaches that started in his late twenties. There were no other significant medical or surgical comorbidities.

He recalled that a paternal uncle previously had a stroke, while another paternal uncle was admitted to a psychiatric hospital and died of an unknown cause. He also noted that his paternal grandfather died of a stroke in his sixties. Unfortunately, most of his family was displaced because of the political unrest in Zimbabwe, and he had lost contact with them.

On admission, the patient had normal vital signs and no evidence of cardiovascular disease. Neurologic examination showed intact language function. Examination of the motor system revealed a right hemiparesis, with symmetrical brisk reflexes. Sensation was normal, as was coordination.

Laboratory tests, including full blood count, lipogram, fasting glucose, HIV serology, syphilis serology, antinuclear factor, and erythrocyte sedimentation rate were all normal. ECG, carotid Doppler, and transthoracic echocardiogram were normal.

MRI detected T2 bilateral deep periventricular white matter hyperintensities. These lesions were especially confluent in the centrum semiovale (figure). There were also bilateral subcortical lesions in the anterior temporal lobes and diffuse cerebral atrophy.

Given a history of migraines and a history of young-onset stroke in the patient's family, a diagnosis of CADASIL was considered.

From the Department of Neurology, Tygerberg Academic Hospital, University of Stellenbosch, Cape Town, South Africa.

Funding information and disclosures are provided at the end of the article. Full disclosure form information provided by the authors is available with the full text of this article at Neurology.org/NG.

The Article Processing Charge was waived at the discretion of the Editor.

This is an open access article distributed under the terms of the Creative Commons Attribution-NonCommercial-NoDerivatives License 4.0 (CC BY-NC-ND), which permits downloading and sharing the work provided it is properly cited. The work cannot be changed in any way or used commercially without permission from the journal. 
Figure T2 FLAIR images depict subcortical lesions in the anterior temporal lobes and deep white matter with confluent centrum semiovale hyperintensities

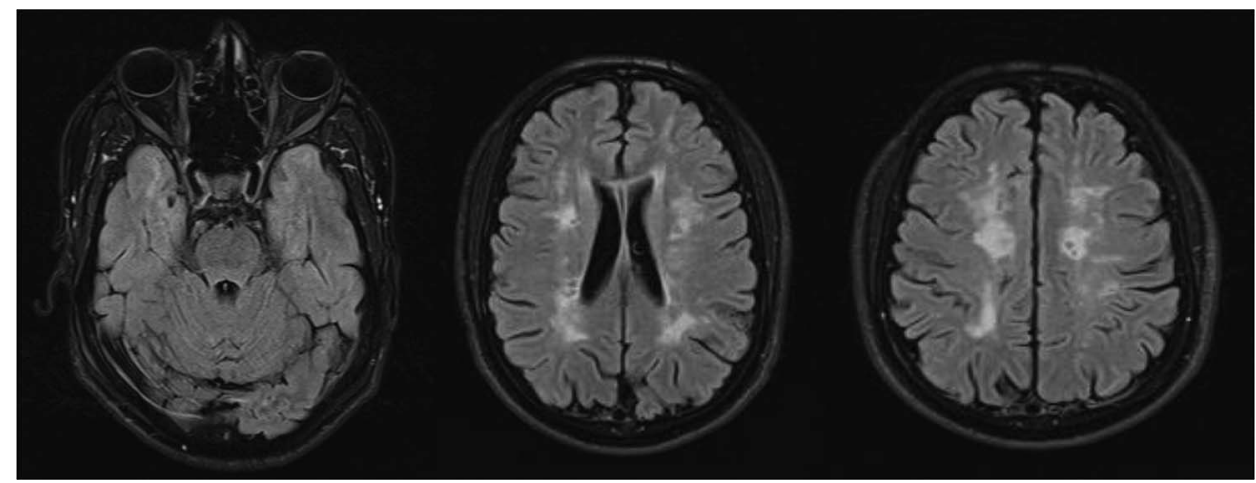

Molecular genetic analysis of the Notch3 gene was performed. This revealed a heterozygous missense mutation, which resulted in a substitution of a cysteine for serine amino acid at codon 183 within exon 4 . The patient's family could not be tested as they remained in Zimbabwe at the time of diagnosis.

\section{Discussion}

Since the discovery of the Notch 3 mutation in 1993, many patients with CADASIL have been identified worldwide. It is rare to identify a CADASIL mutation in a black indigenous African patient. However, the disease progression and imaging findings are typical, and the specific mutation has been previously identified in other confirmed cases. ${ }^{5}$

Our patient is originally from the eastern highlands of Zimbabwe. This mountainous region range forms a natural border with neighboring Mozambique, which was previously a Portuguese colony. Although speculative, it is possible that the mutation could have been introduced by a Portuguese immigrant, accounting for how this typically Caucasian mutation was found in this patient. In addition, the specific mutation (c. $547 \mathrm{~T}>\mathrm{A}$; p. Cys183Ser) has also been described in other European families. ${ }^{6}$

De novo mutations have been described in syndromic patients without a significant family history. Furthermore, CADASIL-causing mutations cluster in regions of sequence diversity and low evolutionary conservation. ${ }^{7}$ Thus, the possibility exists that the mutation may have arisen spontaneously.
In the correct clinical context, along with suggestive MRI findings, CADASIL could be considered in a young-onset stroke patient, regardless of his or her ancestry.

\section{Author contributions}

L. Vlok: writing of the initial draft of the manuscript, design, and conceptualization of the study. N. Brey: critical revision of the manuscript for intellectual concept.

\section{Study funding}

No targeted funding received.

\section{Disclosure}

L. Vlok is a registrar in neurology at the University of Stellenbosch (receives bursary from the Mediclinic private hospital group). N. Brey reports no disclosures. Full disclosure form information provided by the authors is available with the full text of this article at Neurology.org/NG.

Received April 10, 2018. Accepted in final form June 18, 2018.

\section{References}

1. Chabriat H, Joutel A, Dichgans M, Tournier-Lasserve E, Bousser MG. Cadasil. Lancet Neurol 2009;8:643-653.

2. Bohlega S, Al Shubili A, Edris A, et al. CADASIL in Arabs: clinical and genetic findings. BMC Med Genet 2007;8:67.

3. Tan ZX, Li FF, Qu YY, Liu J, et al. Identification of a known mutation in Notch 3 in familiar CADASIL in China. PLoS One 2012;7:e36590.

4. Lee SL, Meng H, Elmadhoun O, et al. Cerebral autosomal dominant arteriopathy with subcortical infarcts and leukoencephalopathy affecting an African American man: identification of a novel 15-base pair NOTCH3 duplication. Arch Neurol 2011;68 1584-1586.

5. Rutten J, Haan J, Terwindt G, Van Duinen S, Boon E. Interpretation of NOTCH3 mutations in the diagnosis of CADASIL. Expert Rev Mol Diagn 2014;14:593-603.

6. Dichgans M, Ludwig H, Müller-Höcker J, Messerschmidt A, Gasser T. Small in-frame deletions and missense mutations in CADASIL: 3D models predict misfolding of Notch3 EGF-like repeat domains. Eur J Hum Genet 2000;8:280-285.

7. Donahue CP, Kosik KS. Distribution pattern of Notch3 mutations suggests a gain-offunction mechanism for CADASIL. Genomics 2004;83:59-65. 


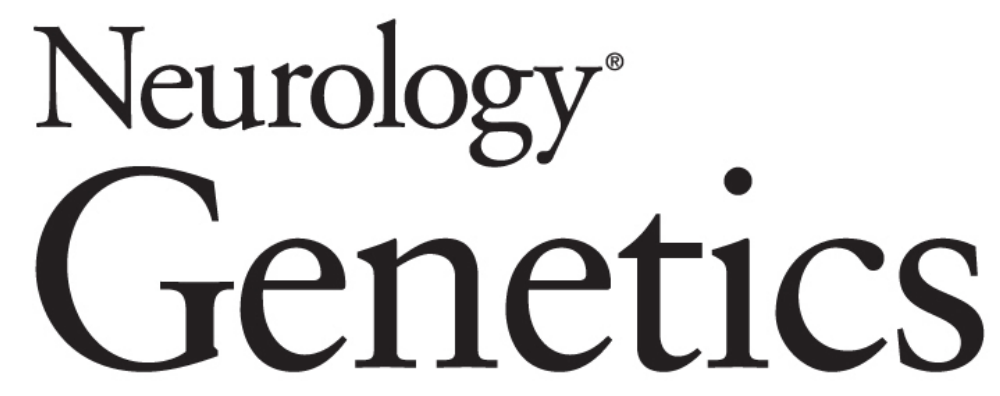

CADASIL affecting a black African man
Louis Vlok and Naeem Brey
Neurol Genet 2018;4;
DOI 10.1212/NXG.0000000000000270

This information is current as of September 19, 2018

\section{Updated Information \&} Services

\section{References}

Subspecialty Collections

\section{Permissions \& Licensing}

\section{Reprints}

including high resolution figures, can be found at: http://ng.neurology.org/content/4/5/e270.full.html

This article cites 7 articles, 0 of which you can access for free at: http://ng.neurology.org/content/4/5/e270.full.html\#\#ref-list-1

This article, along with others on similar topics, appears in the following collection(s):

All Genetics

http://ng.neurology.org//cgi/collection/all_genetics

Stroke in young adults

http://ng.neurology.org//cgi/collection/stroke_in_young_adults Underserved populations

http://ng.neurology.org//cgi/collection/underserved_populations

Information about reproducing this article in parts (figures,tables) or in its entirety can be found online at:

http://ng.neurology.org/misc/about.xhtml\#permissions

Information about ordering reprints can be found online:

http://ng.neurology.org/misc/addir.xhtml\#reprintsus

Neurol Genet is an official journal of the American Academy of Neurology. Published since April 2015, it is an open-access, online-only, continuous publication journal. Copyright Copyright $\odot 2018$ The Author(s). Published by Wolters Kluwer Health, Inc. on behalf of the American Academy of Neurology.. All rights reserved. Online ISSN: 2376-7839.

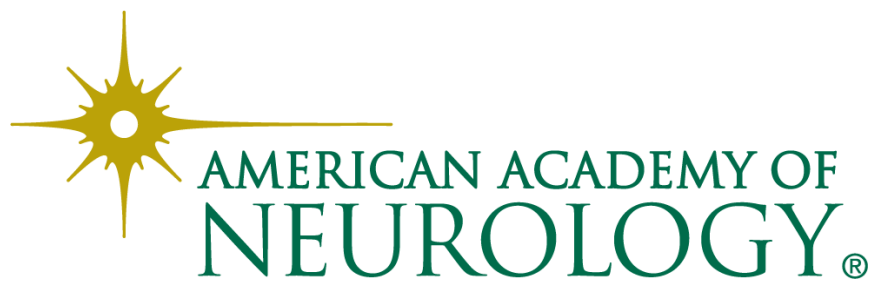

